\title{
〔一般講 演〕
}

\section{（1）においセンサーの坑内適応化}

資源環境技術総合研究所(北海道)

"I

3.においセンサーの動作原理

人間の鼻は、一般的ににおい分子を鼻の嗅上皮細胞の脂質二分 子膜部分に吸着させ、膜電位変化を神経に伝達する構造と考えら れている3)。そこで、におい物質が吸着しやすい合成二分子膜を 検討した結果、ジアルキルアンモニウム塩二分子膜とポリスチレ ンスルホン酸のイオンコンプレックスからなる膜が考案された ${ }^{3) 。 ~}$ この膜を水晶発振子の電極に取り付汀る形でセンサーが構成され ている。この素子膜に各種のにおいガスが吸着すると、二分子膜 の質量変化が生じ、下式のように共振周波数が変化する4)。

$\mathrm{d} \mathrm{f}=-2 \cdot \mathrm{f}^{2} /(\nu \cdot \mathrm{S} \cdot \rho \mathrm{q}) \cdot \Delta \mathrm{M}$

ここで、f は基本共振周波数、 $\mathrm{S}$ は電極面積、vは共振子厚み 方向に伝搬するバルク横波速度 $(3320 \mathrm{~m} / \mathrm{s})$ ） $\rho \mathrm{q}$ は水晶の密度2. $65 \times 10^{3} \mathrm{~kg} / \mathrm{m}^{3} 、 \Delta \mathrm{M}$ は質量変化である。今回使用した水晶発振子 は、ATカットタイプで、 $\mathrm{f}=9 \mathrm{MHz} 、 \mathrm{~S}=0.5 \mathrm{~cm}^{2}$ ののであり、 この素子を用いると約 $0.37 \mathrm{~Hz} / \mathrm{ng}$ の感度が得られる。つまり、数 $\mathrm{Hz}$ 程度の周波数変化の測定が可能であれば、約 $10 \mathrm{ng}$ 程度のにお いの質量変化が検知可能であろう。

次に干渉ガス（におい）としては、においがあり分子量が大き なものに関しては選択して出力変化することはできないが、メタ ンやCOなどの無臭で分子量が少ないものに関しては出力变化が ない。このためエレメントなどを利用した他のにおいセンサーと 比較して、坑内での使用には有利な特長がある。

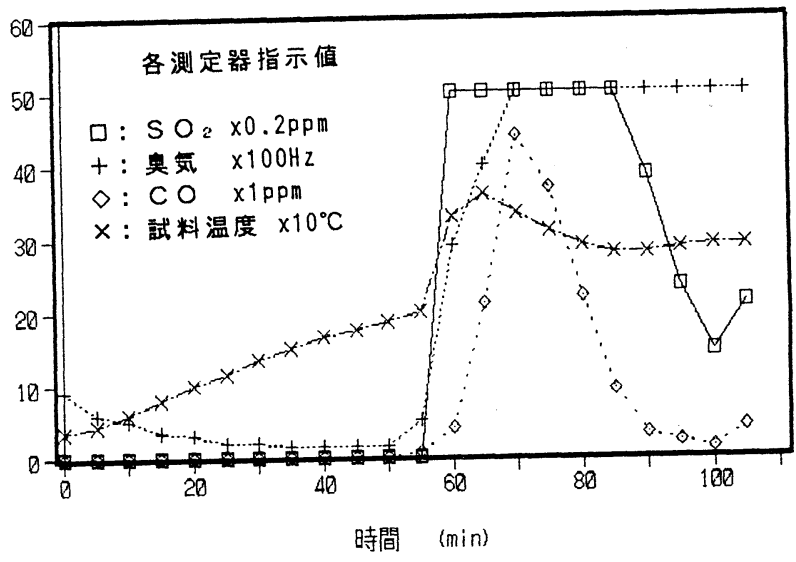

試料：ベルト, NN300風速 $1.0 \mathrm{~m} / \mathrm{sec}$

Fig. 2 An example data obtained by the belt combustion

Fig. 1 Conveyer-belt combustion test apparatus using smell sensor 
4. 坑内火災検知におけるに㧧いセンサーの動作特性

たとえば、ベルトコンベア、ケーブル等が然焼すると、通常坑 内には存在しない $\mathrm{SO}_{2}$ ガスなどが発生するため、これらのガス を検知し坑内火災の有無を判断する方法を我々は提案している しかし、これらに使用される定電位電解式ガスセンサーは、0.1p pm以下のガス濃度を高精度に検知するといら点では難しい。そこ で、ベルトユンベア、ケーブル等が燃焼するこ COPS $\mathrm{O}_{2}$ ガス以 外に特有なにおいが発生することから、においセンサーの有効性 について検討した。実験方法は実験室内の燃焼風洞を使用し、実 際に坑内で使用しているべルトコンベアを常温状態から徐々に加 熱し、その時発生するガス等を実験風洞内に設置したに㧧いセン サーに加え、時間による変化を測定した6〉。Fig.1亿装置構成を示 す。燃焼風洞は直径 $0.3 \mathrm{~m}$ 、一本 $2 \mathrm{~m}$ の円筒管を 5 本連結し、全舆 10 mである。燃焼炉はニクロム線によって全周から加熱する構造であ る。送風方法は、ファンによる吸い込み方式で行った。測定器は においセンサーの他に定電位電解式COセンサー $(0 \sim 50 \mathrm{ppm}) 、 \mathrm{~S}$ $\mathrm{O}_{2}$ ガスセンサー $(0 \sim 10 \mathrm{ppm})$ 、風速計 $(0 \sim 10 \mathrm{~m} / \mathrm{s})$ を配置し測定し た。ベルトの試験片は、大きさが約 $0.15 \times 0.07 \times 0.015 \mathrm{~m}$ 程度のも のを使用し、燃焼炉に銅板を入れ、その上に置く方法で加熱した。 また、試験片と板との間に熱電対を挟み、その温度を試料温度と した。温度上昇カーブは常温状態から約 1 時間で $100^{\circ} \mathrm{C}$ 程度の上昇 になるように設定した。今回の実験では、においセンサーの水晶 発振子は悪臭物質（硫化メチルなど）や一般的な有㙨溶媒等に感 度の高い素子（以下高感度タイプ）を使用した。Fig.2k、その実 験結果の一例を示す。眓から、C においセンサーも上昇変化時期がほぽ同じであることから、にお いセンサーが坑内火災の検知に利用可能であることが示された。

5.においセンサーの坑内適応化

5.1 坑内用においセンサーの試作

今回開発する坑内用においセンサーは、一般分野においても利 用され始めたばかりの機器である。そのような機器を防爆化した 場合、坑内でトラブル等が発生した場合に対処が難しいことが予 想される。過去において各種センサーの防爆化を行う場合、何度

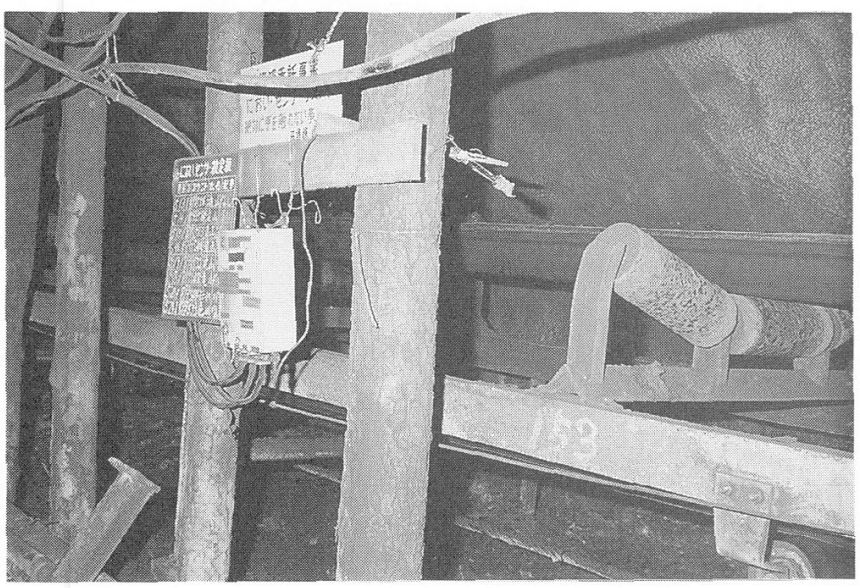

Fig. 3 Smell sensor installed at the test site
も改良を加えながら対処することが一般的であるが、現場関係者 から早急にに㧍いセンサーの防爆化の強い要望があることから、 今回はとりあえず本質安全防爆構造に準拠したにおいセンサーを 試作（未検定品）し、通常坑内の特免区域に扎いて基本データの 収集を行い、坑内環境に扮けるにおいの挙動変化を調査すること にした7》。これから得られたデータは、後述する本質安全防爆型 坑内用に括いセンサーの開発に役立てることにした。

Fig. 3に、坑内における設置状況を示す。試作器は市販品とは別 の電気回路であり、以下その特長を示す。第 1 に、各素子の初期 周波数值のばらつきがあるため、周波数変換部を $9.5 \mathrm{MHz}$ 名ら $8.0 \mathrm{M}$ $\mathrm{Hz}$ の広範囲の周波数変化に対応する回路にした。実際のにおい変 化は数 $\mathrm{KH} z$ 程度のため、従来の0.2〜1mA等の電流出力ではにおいの 変化量が出力に現れにくいので、 $9(8)$.*****MHzの上位 3 桁 (9.5 0から8.00まで）の出力と、その下の下位 3 桁（999から000まで） の出力の 2 系統による力式とした。さらに内部のスパン調整ボリ エームで、きめ細か外調整を可能にした〈たとえば実際の周波数 変化が9.01***から $8.90 * * * \mathrm{MHz}$ の場合は、上位桁 9.01 の時 $0.2 \mathrm{~mA}$ 、 8. 90 の時 $1 \mathrm{~mA}$ にるようにスパンを調整する）。第 2 に、表示方式 をデジタル6桁の周波数表示にした。これによって、に持いセン サーが異常の場合の判定を行いやすくした。第 3 に、本体朔面は デジタル表示部とスイッチのみ（ON、OFF、回路リセット）とし、 初心者でも扱い易くした。

上記の機器を、坑内現場（人気側ベルトコンベア坑道）に約 1 0 カ月設置し現場データを記録しているが、大きなトラブルもな く順調に動作を行っている。

\section{2 坑内におけるにおいの挙動変化}

Fig. 4に、坑内のにおいの変化の一例を示す。においセンサー素 子は特性別に 4 種類あるが、ベルトコンベア等の初期燃焼状態を 検知する目的で設置しているため、前記と同様の高感度タイプを 利用した。においセンサーの挙動変化は、特免区域（入気側）に 設置しているとはいえ、我々の予想よりも小さな変化量であった。 原因として考えられることは、水晶発振子に粉じん等が付着し、 寿命が短くなるのを防ぐため検知部に通気抵抗にならない程度の 薄いガーゼを巻いており、それがにおいのフィルターとなり実際

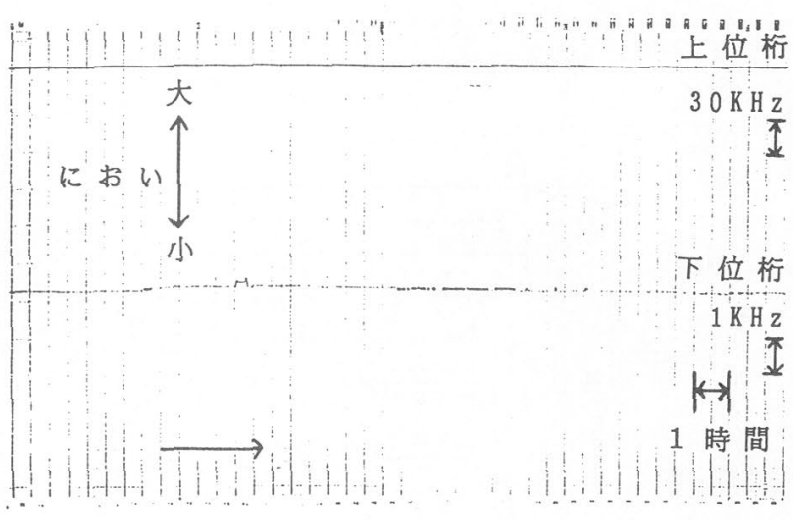

Fig. 4 A smell chart in coal mine 
のにおいよりも弱く素子に伝わっていることが考えられる。また、 COセンサー等のガスセンサー出力と比較した場合、同様の動き をしている部分があまりなかった。ベルトコンベア運転とにおい の変化については、相関がとれた部分もあった。ただ、限られた ガスセンサーしかにおいセンサーと併設されていないため、何の ガス成分を検知しているのかは不明である。また水晶発振子は、 現在のところ最小で 4 カ月程度使用可能であった。ただし、今回 は入気側の比較的坑内環境が良好な場所で実験を行っているので 詳しい寿命については不明である。さらに一般的纪においの水晶 発振子は、高湿度中では動作特性が劣るので、排気側での特性に ついても不明である。

\section{3 本質安全防爆型においセンサーの開発}

前記したように水晶発振子を利用したにおいセンサーは市販さ れているが8)、炭鉱坑内のどのような環境でも使用するためには、 そのままの形で利用することはできない。そこで前記した害績を 踏まえ、においセンサーの坑内用本質安全防爆化を行った。

最初にに执いセンサーの電気回路について、本質安全性を検討 した。センサー部は水晶発振子及び発振回路からなっており、こ れらはすべて本質安全を十分満足する仕様になっている。

次に指示部については、市販品は商用電源を用いることや各種 インターフェイス等を備えていることから、このままの形では本 質安全性を満足しないため、新たな設計を行った。電源部につい ては、坑内で広く利用されているメタンガス検知器用の電源箱を 利用する構造にした。また、センサー部から送られてくる周波数 信号を変換する回路については、市販品同様マイクロコンピュー タを利用した方式で、センサー部から送られてくるにおい物質に よる周波数変化（固有振動数）を 7 桁のデジタル表示（以下表示 A）で行う。さらに、無臭の空気、あるいは一定臭気で安定状態 になったポイントを基準の 0 点と決め（前面押しボタンによる）、 表示 $\mathrm{A}$ の下 4 桁をさらにデジタル表示（以下表示B）し、その点 から変化する周波数を \pm 4 桁のデジタル表示（以下表示C）で行

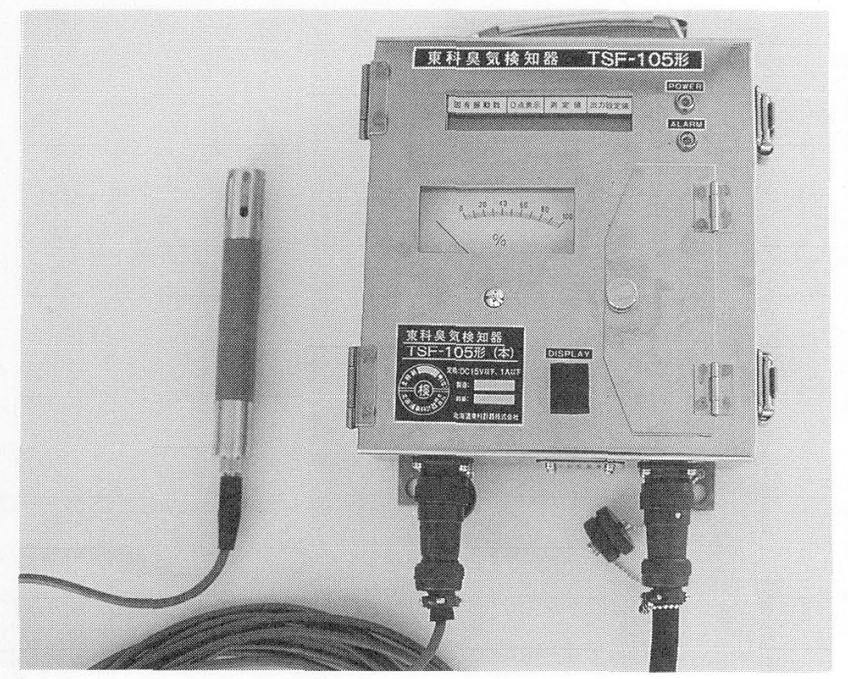

Fig. 5 The appearance of the smell sensor developed
うようになっている。出力設定は 4 桁の任意の最大変化值（以下 表示D）を前面のスイッチにより入力し、表示 Dまで周波数が変 化した場合に、フルスケール1 mAの外部出力になるように設定する $(0$ 点 $(0.2 \mathrm{~mA})$ は、表示 $\mathrm{B}$ の值) 。なお、この変化は同時に前面の アナログメーター $(0 \sim 100 \%)$ とも表示される。この結果、部品点数 も減り消費電力等も少なくなったことから、JIS C 0901に準拠し た本質安全性を満足する検知器が可能になった。Fig.5 防爆型に おいセンサーの外観㘠を示す。大きさは、センサー部が直径約 22 $\mathrm{mm}$ 、長さ $220 \mathrm{~mm}$ で粉じん対策として金属フィルターを備えている。 また、指示部は2 $18 \times 312 \times 90 \mathrm{~mm}$ でセンサー部と指示部はコネクタ で接続する構造になっており、最大 $10 \mathrm{~m}$ ま゙離すことが可能である。

6.まとめ

水晶発振子を利用した、においセンサーの坑内適応化について 検討し、本質安全防爆型坑内用に括いセンサーを開発した。近日 中に、坑内において排気側を中心に温度の影響や発破跡ガス等に 含まれる雑ガスの影響を含めた、各種適応化試験を開始する予定 である。においセンサーとしては高感度ではあるものの、人間の 鼻のように各種のにおいを区別することは、現段階では難しい。

今後はこれらの点について検討し、坑内に括汁る各種動作特性 等について、実験を行っていく予定である。最後に、坑内用にお いセンサーの開発に当たっては、相互薬工（株）、（財）石炭技 術研究所、北海道東科計器（株）の方々に、現場実験に当たって は、太平洋炭鉱釧路鉱業所及び同共通課の方々の多大な協力を頂 いたことに対し、謝意を表する。

\section{〔参考文献〕}

1) 渡辺浩二他：ニオイセンサーの食品関連分野での利用、食品と 科学、V01.31、No.7(1989)

2) 山尾信一郎他：公害資源研究所報告、第37号 (1986)

3) 岡畑恵雄：脂質二分子膜を利用したにおいセンサ、センサ技術、 Vol.9、No.2 2(1989)

4) 中本高道他 : ニューラルネットワークを用いたにおいセンサー、 応用物理、Vol.58、No.7、PP1045-1054(1989)

5) 野田和俊他 : 坑内火災用新型検知器の開発、資源と素材、V01. 105、No.11、PP 818-820(1989)

6) 野田和俊他：坑内用に扮いセンサの開発、資源・素材学会北海 道支部平成 2 年度春季講演会要旨集、 PP9-10(1990)

7) 野田和俊他：坑内にお汀るにおいの挙動変化、資源・素材学会 北海道支部平成 3 年度春季講演会要旨集、 PP15-16 (1991)

8)相互薬工（株）製 Fragrance Meter SF-105 